\title{
Effect of temperature and food concentration on the relationship between growth and AARS activity in Paracartia grani nauplii
}

\author{
Inma Herrera ${ }^{\mathrm{a}, *}$, Lidia Yebra ${ }^{\mathrm{b}}$, Santiago Hernández-Léon ${ }^{\mathrm{a}}$ \\ a Institute of Oceanography and Global Change, Universidad de Las Palmas de Gran Canaria, 35017 Las Palmas de Gran Canaria, Spain \\ b Instituto Español de Oceanografía, Centro Oceanográfico de Málaga, Apdo. 285, 29640 Fuengirola, Málaga, Spain
}

\section{A R T I C L E I N F O}

Article history:

Received 12 October 2011

Received in revised form 22 February 2012

Accepted 23 February 2012

Available online 19 March 2012

\section{Keywords:}

AARS

Food concentration

Growth

Paracartia grani

Protein metabolism

Temperature

\begin{abstract}
A B S T R A C T
The in situ activity of the enzymes aminoacyl-tRNA synthetases (AARS) and the growth rates of naupliar stages of the planktonic marine copepod Paracartia grani were measured in the laboratory under different temperature and food concentrations. We assessed the effect of these parameters on growth and protein synthesis rates of $P$. grani nauplii. Growth and protein synthesis rates of $P$. grani nauplii depended on temperature and food concentration. AARS activity is valid as an index of somatic growth for $P$. grani nauplii when growth is not limited by food availability. However, the relationship between protein-specific AARS activity and nauplii growth varied according to food availability levels. The degradation of proteins during starvation and/or the ß-oxidation of fatty acids affected the relationship between specific AARS activity and growth rates. The results presented here add to previous studies showing that the AARS activity is a useful tool for estimating somatic growth of this and other key copepod species. Nevertheless, further research is required to elucidate the validity of AARS activity as a universal proxy for growth.
\end{abstract}

(c) 2012 Elsevier B.V. All rights reserved.

\section{Introduction}

The assessment of zooplankton production is a milestone in oceanography. Zooplankton is the main link between the primary producers and fisheries, and they are also important in the flux of energy and matter in the ocean. From this point of view, it is of interest to know which changes may produce temperature and food concentration variations on the growth rates of early developmental stages of key zooplankton species.

There are an increasing number of approaches to estimate growth rates in planktonic organisms such as copepods (Runge and Roff, 2000). Traditionally, the direct method (Heinle, 1966), based on length or weight increases, and the egg production rate method (EPR, Marshall and Orr, 1955) have been applied to assess copepod growth rates. EPR is currently the most used method to estimate copepod growth (Hirst et al., 2003) and it is rather sensitive to changes in environmental variables (Saiz et al., 1997). However, the assumption that EPR is comparable to the growth rates of the juveniles is often invalid (Hirst and Bunker, 2003). Also, adult females may lose or gain weight while producing eggs, and as such, EPR may not accurately represent growth of the female (Hirst and McKinnon, 2001). In addition, EPR measurements are labor consuming and involve a risk of introducing artifacts due to the handling of the animals (Jones, 1980).

\footnotetext{
* Corresponding author. Tel.: + 34 928454546; fax: + 34928452922.

E-mail addresses: iherrera@becarios.ulpgc.es (I. Herrera), lidia.yebra@ma.ieo.es (L. Yebra), shernandez@dbio.ulpgc.es (S. Hernández-Léon).
}

In recent years, the use of biochemical methods as indices of growth in copepods has increased. These methods allow the assessment of zooplankton production on field collected organisms with less laboratory manipulation and are mainly based on either biomass ratios (e. g. RNA/DNA, Dagg and Littlepage, 1972; RNA/protein, Gorokhova, 2003; Saiz et al., 1998; Wagner et al., 2001) or the activity of enzymes involved in the process of growth (e.g. nucleoside diphosphate kinase NDPK, Berges et al., 1990; aspartate transcarbamylase ATC, Bergeron and Buestel, 1979; Biegala and Bergeron, 1998; chitobiase, Oosterhuis et al., 2000; Sastri and Roff, 2000). An enzymatic method, recently developed as index of copepod somatic growth, is based on the activity of the aminoacyl-tRNA synthetases (AARS, Yebra and Hernández-León, 2004). These enzymes catalyze the first step of the protein synthesis and their activity is significantly related to somatic growth in freshwater and marine crustaceans (Daphnia magna, Yebra and Hernández-León, 2004; Calanus helgolandicus, Yebra et al., 2005; Calanus finmarchicus, Yebra et al., 2006; Euphausia superba, Guerra, 2006).

In order to assess the effect of temperature and food concentration on their somatic growth and protein synthesis rates (AARS activity), as well as the relationship between both variables, we studied Paracartia grani nauplii. Copepods of the family Acartiidae are common in coastal and estuarine habitats worldwide (see Rosamma and Rao, 1985). They are mainly adapted to the high food concentrations normally found in estuaries and upwelled waters (Paffenhöfer and Stearns, 1988). As they are the principal link in the marine food web in some areas, there are many studies on growth of the genus Acartia (e.g. Berggreen et al., 1988; Bersano, 2000; Durbin and 
Durbin, 1978; Gorokhova, 2003; Klein Breteler and Gonzalez, 1982; Landry, 1978; Leandro et al., 2006; Saiz et al., 1998). However, their nauplii growth rates have rarely been described (Berggreen et al., 1988; Calbet and Alcaraz, 1997; Durbin and Durbin, 1978; Leandro and Tiselius, 2006).

In this work, we focused on the effect of temperature and food quantity on the growth and AARS activity of $P$. grani (Sars, 1904) nauplii. In order to assert the use of this enzyme as a proxy for growth rates in the ocean, a parallel response of its activity and rates should be expected.

\section{Material and methods}

\subsection{Parental cultures}

P. grani Sars, 1904 (Copepoda: Calanoida) and Oxyrrhis marina (heterotrophic dinoflagellate, equivalent spherical diameter, $\mathrm{ESD}=16.9 \mu \mathrm{m})$ were obtained from continuous cultures maintained at the Institute of Marine Sciences (ICM, Barcelona, Spain). They were kept in 20 L transparent plastic tanks and $2 \mathrm{~L}$ pyrex bottles respectively, at $20^{\circ} \mathrm{C}$ with a 12:12 h photoperiod. P. grani and O. marina were fed with Rhodomonas baltica (Cryptophyceae, ESD $=8 \mu \mathrm{m}$ ), grown at $20^{\circ} \mathrm{C}$ on $\mathrm{f} / 2$ medium (Guillard, 1975). Every $24 \mathrm{~h}$, the eggs of P. grani were collected and refrigerated $\left(4^{\circ} \mathrm{C}\right)$ until used for experiments (between 2 and 30 days).

\subsection{Experiments at different temperatures}

Organisms were acclimated at different temperatures using six water baths (Table 1). In each of them we introduced a plastic container with $10 \mathrm{~L}$ of filtered sea water. Once the water reached the desired temperature we added the previously refrigerated eggs to each container and allowed $16 \mathrm{~h}$ for them to hatch. Each group of nauplii ( 2 nauplii $\mathrm{mL}^{-1}$ ) was grown under food saturating conditions (Calbet and Alcaraz, 1997). The nauplii were fed with O. marina (10001300 cells $\cdot \mathrm{mL}^{-1} ; \quad 220-286 \mu \mathrm{g} \mathrm{C} \cdot \mathrm{L}^{-1}$, assuming $215.8 \mathrm{pg} \mathrm{C} \cdot$ cells $^{-1}$ from Klein Breteler and Schogt, 1994). Food concentration was measured daily with a Multisizer Coulter Counter. Every 12-24 h (depending on the experimental temperature) we took an aliquot of $100 \mathrm{~mL}$ from the nauplii culture and fixed it with Lugol's acid solution for abundance and individuals' length measurement. Three replicates of approx. 1000 individuals were sampled daily and frozen immediately in liquid nitrogen $\left(-196{ }^{\circ} \mathrm{C}\right)$ for AARS activity assays. Sampling continued for 4-6 days until the nauplii reached the stage VI (NVI).

\subsection{Experiments under different food concentrations}

Nauplii of $P$. grani were acclimated at $20{ }^{\circ} \mathrm{C}$ in seven water baths. Eggs were allowed to hatch during $24 \mathrm{~h}$, and a similar amount of nauplii ( 2 nauplii $\left.\mathrm{mL}^{-1}\right)$ were incubated in $10 \mathrm{~L}$ plastic containers. Each group of nauplii was grown under different concentrations of 0 . marina (Table 2). Food concentration was measured daily with a Multisizer Coulter Counter. Every $24 \mathrm{~h}$ we took three aliquots of $50 \mathrm{~mL}$ from the nauplii culture and fixed them with Lugol's acid solution

\section{Table 1}

Paracartia grani nauplii somatic growth $\left(\mathrm{d}^{-1}\right)$ and protein synthesis rates [spAARS $\left(\mathrm{nmPPi} \cdot \mathrm{mg} \operatorname{prot}^{-1} \cdot \mathrm{h}^{-1}\right)$ and individual AARS $\left.\left(\mathrm{nmPPi} \cdot \mathrm{ind}^{-1} \cdot \mathrm{h}^{-1}\right)\right]$ at different temperatures $\left({ }^{\circ} \mathrm{C}\right) . \mathrm{n}$ is the number of either individuals sized or samples analyzed.

\begin{tabular}{llcl}
\hline $\begin{array}{l}\mathrm{T} \\
\left({ }^{\circ} \mathrm{C}\right)\end{array}$ & $\begin{array}{l}\text { Somatic growth }\left(\mathrm{d}^{-1}\right) \\
\left(\mathrm{r}^{2}, \mathrm{n}\right)\end{array}$ & $\begin{array}{l}\mathrm{SpAARS}_{\mathrm{s}} \pm \mathrm{SE}(\mathrm{n}) \\
\left(\mathrm{nmPPi} \cdot \mathrm{mg} \mathrm{prot}{ }^{-1} \cdot \mathrm{h}^{-1}\right)\end{array}$ & $\begin{array}{l}\text { individual AARS } \\
\left(\mathrm{nmPP} \cdot \mathrm{ind}^{-1} \cdot \mathrm{h}^{-1}\right)\end{array}$ \\
\hline 12 & $0.28(0.990,382)$ & $24.35 \pm 0.69(9)$ & $0.003 \pm 0.000(9)$ \\
16 & $0.41(0.987,480)$ & $49.13 \pm 7.04(9)$ & $0.006 \pm 0.001(9)$ \\
19.8 & $0.54(0.987,188)$ & $50.26 \pm 1.81(8)$ & $0.007 \pm 0.002(8)$ \\
24 & $0.70(0.970,299)$ & $96.79 \pm 5.08(6)$ & $0.019 \pm 0.007(6)$ \\
26 & $0.85(0.973,430)$ & $102.23 \pm 19.72(6)$ & $0.016 \pm 0.005(6)$ \\
28 & $0.85(0.962,597)$ & $106.44 \pm 13.32(9)$ & $0.017 \pm 0.007(9)$ \\
\hline
\end{tabular}

for abundance and individuals' length measurement. Three replicates of approximately 1000 individuals were sampled and frozen immediately in liquid nitrogen $\left(-196{ }^{\circ} \mathrm{C}\right)$ to assess AARS activity. Sampling continued for 5-8 days, until the nauplii reached stage NVI.

\subsection{Growth calculations}

Organisms fixed in Lugol's were photographed using a camera connected to a dissecting microscope at $40 \times$ magnification. Prosome length $(\mu \mathrm{m})$ was measured from pictures with Image/J software. Individual biomass of $P$. grani nauplii was estimated from the length-dry weight (dw) equation given by Durbin and Durbin (1978) for Acartia clausi:

$W=19.04 \cdot L^{2.849}, r^{2}=0.98$

where $\mathrm{W}$ is body weight in $\mu \mathrm{g} \mathrm{dw}$ and $\mathrm{L}$ is prosome length in $\mathrm{mm}$.

Dry weight (dw) was converted to carbon (C) assuming a carbon/dry weight ratio of 0.40 (Postel et al., 2000). Weight-specific growth rates $\left(\mathrm{G} . \mathrm{d}^{-1}\right)$ were calculated as the slope of $\ln$ (weight) increases over time.

The temperature quotient $\left(\mathrm{Q}_{10}\right)$ of growth rates and AARS activities was calculated as: $\mathrm{Q}_{10}=(\mathrm{M} 1 / \mathrm{M} 2)^{10(\mathrm{~T} 2-\mathrm{T} 1)}$, where $\mathrm{M} 2$ and $\mathrm{M} 1$ are the rates of the studied processes at temperatures $\mathrm{T} 2$ and $\mathrm{T} 1\left({ }^{\circ} \mathrm{C}\right)$, respectively. In order to use a $10{ }^{\circ} \mathrm{C}$ range, we calculated the $\mathrm{Q}_{10}$ between 16 and $26^{\circ} \mathrm{C}$.

\subsection{AARS activity assay}

Frozen samples were homogenized in Tris- $\mathrm{HCl}$ buffer $(20 \mathrm{mM}, \mathrm{pH}$ 7.8 ) and centrifuged $\left(10 \mathrm{~min}, 0^{\circ} \mathrm{C}\right)$. AARS activity was assayed following the method of Yebra and Hernández-León (2004), slightly modified as follows: $250 \mu \mathrm{L}$ of each sample supernatant was added to a mixture containing $200 \mu \mathrm{L}$ of pyrophosphate (PPi) reagent (P-7275, from Sigma) and $300 \mu \mathrm{L}$ of Milli-Q water at room temperature. The absorbance of the reaction mixture was monitored at $340 \mathrm{~nm}$ for $10 \mathrm{~min}$ at $25^{\circ} \mathrm{C}$. The aminoacylation of the tRNA releases PPi, which produces an oxidation of NADH. This is registered as a decrease in absorbance $(\mathrm{dA})$. The NADH oxidation rate $\left(\mathrm{dA} \cdot \mathrm{min}^{-1}\right)$ was converted to PPi release rate (AARS activity, $\mathrm{nmPPi} \cdot \mathrm{mL}^{-1} \cdot \mathrm{min}^{-1}$ ) using the equation (1) in Yebra and HernándezLeón (2004):

$n$ mol PPi $\cdot \mathrm{h}^{-1}$. sample $\mathrm{mL}^{-1}=\left(\mathrm{dA} \cdot \min ^{-1} \cdot 10^{3} \cdot 60\right) \cdot\left(V_{r m} \cdot 6.22 \cdot 2\right)^{-1}$

where $V_{\mathrm{rm}}$ is the volume of the reaction mixture in $\mathrm{mL}, 6.22$ is the millimolar absorptivity of NADH at $340 \mathrm{~nm}$ and 2 is the number of moles of $\beta$-NADH oxidized per mole of PPi consumed.

AARS activity was corrected for the in situ temperature of each experiment by applying an activation energy of $8.57 \mathrm{kcal} \cdot \mathrm{mol}^{-1}$ (Yebra et al., 2005) to the Arrhenius equation in order to obtain the in situ activity $\left(\right.$ AARS $\left._{s}\right)$.

Protein content of the samples was measured following the Lowry et al. (1951) method adapted for micro-assay by Rutter (1967), using Bovin Serum Albumin as standard (A-4503, from Sigma).

\section{Results}

\subsection{Effect of temperature on nauplii rates}

Weight-specific growth rates (slope of each regression line in Fig. 1), varied from 0.28 to $0.85 \mathrm{~d}^{-1}$ between 12 and $28{ }^{\circ} \mathrm{C}$ (Table 1). The protein-specific AARS $_{\mathrm{S}}\left(\mathrm{spAARS}_{\mathrm{s}}\right.$, Table 1) ranged from 24.35 to $106.44 \mathrm{nmPPi} \cdot \mathrm{mg} \mathrm{prot}^{-1} \cdot \mathrm{h}^{-1}$ and the individual $\mathrm{AARS}_{\mathrm{s}}$ increased from 0.003 to $0.019 \mathrm{nmPPi} \cdot$ ind $^{-1} \cdot \mathrm{h}^{-1}$. 
Table 2

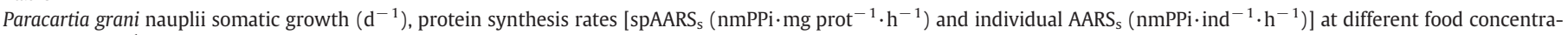
tions $\left(\mu \mathrm{g} \mathrm{C} \cdot \mathrm{L}^{-1}\right) \cdot \mathrm{n}$ is the number of either individuals sized or samples analyzed.

\begin{tabular}{|c|c|c|c|}
\hline $\begin{array}{l}\text { Food concentration } \\
\left(\mu \mathrm{g} \mathrm{C} \cdot \mathrm{L}^{-1}\right)\end{array}$ & $\begin{array}{l}\text { Somatic growth }\left(d^{-1}\right) \\
\left(r^{2}, n\right)\end{array}$ & $\begin{array}{l}\operatorname{spAARS}_{\mathrm{s}} \pm \mathrm{SE}(\mathrm{n}) \\
\left(\mathrm{nmPPi} \cdot \mathrm{mg} \operatorname{prot}^{-1} \cdot \mathrm{h}^{-1}\right)\end{array}$ & $\begin{array}{l}\text { individual AARS } \mathrm{s}_{\mathrm{S}} \pm \mathrm{SE}(\mathrm{n}) \\
\left(\mathrm{nmPPi} \cdot \text { ind }^{-1} \cdot \mathrm{h}^{-1}\right)\end{array}$ \\
\hline 0 & $-0.01(0.604,454)$ & $59.60 \pm 5.18(12)$ & $0.003 \pm 0.000(12)$ \\
\hline 11 & $0.03(0.677,678)$ & $59.02 \pm 12.24(10)$ & $0.004 \pm 0.001(10)$ \\
\hline 55 & $0.34(0.945,740)$ & $46.51 \pm 4.43(12)$ & $0.004 \pm 0.001(12)$ \\
\hline 110 & $0.49(0.935,459)$ & $46.03 \pm 6.84(12)$ & $0.005 \pm 0.001$ \\
\hline 220 & $0.64(0.989,299)$ & $34.80 \pm 11.03$ & $0.006 \pm 0.001$ \\
\hline 440 & $0.68(0.991,482)$ & $32.24 \pm 3.12(9)$ & $0.004 \pm 0.001$ \\
\hline 880 & $0.61(0.945,465)$ & $34.29 \pm 4.60(10)$ & $0.006 \pm 0.001(10)$ \\
\hline
\end{tabular}

Temperature $\left({ }^{\circ} \mathrm{C}\right)$ had a significant positive effect on growth rates $\left(\mathrm{G}, \mathrm{d}^{-1}\right)$ of nauplii (Fig. $\left.2 \mathrm{~A}\right)$ :

$G=-0.188+0.038 \cdot T, r^{2}=0.984, p<0.001$

Also $\mathrm{spAARS}_{\mathrm{s}}\left(\mathrm{nmPPi} \cdot \mathrm{mg} \operatorname{prot}^{-1} \cdot \mathrm{h}^{-1}\right)$ and individual $\mathrm{AARS}_{\mathrm{s}}$ (nmPPi $\cdot$ ind $^{-1} \cdot \mathrm{h}^{-1}$ ) were significantly affected by temperature (Fig. 2B, C):

$\operatorname{spAARS}_{\mathrm{s}}=-42.51+5.44 \cdot T, r^{2}=0.942, p<0.001$

AARS $_{\mathrm{s}} \cdot$ ind $^{-1}=-0.010+0.001 \cdot T, r^{2}=0.852, p<0.001$
The $Q_{10}$ value obtained within the 16 and $26{ }^{\circ} \mathrm{C}$ range was the same for growth rate and specific AARS s (2.1) and was 2.4 for individual AARS $_{s}$.

\subsection{Effect of food concentration on nauplii rates}

Weight-specific growth rates (slope of regression lines in Fig. 3) varied from -0.01 to $0.68 \mathrm{~d}^{-1}$ with increasing food concentrations (Fig. 4A) and the average spAARS s ranged between 32.24 and $59.60 \mathrm{nmPPi} \cdot \mathrm{mg} \operatorname{prot}^{-1} \cdot \mathrm{h}^{-1}$ (Table 2 ). The average AARS per individual increased from 0.003 to $0.006 \mathrm{nmPPi} \cdot$ ind $^{-1} \cdot \mathrm{h}^{-1}$ (Table 2) and presented high variability within experiments. The assumption
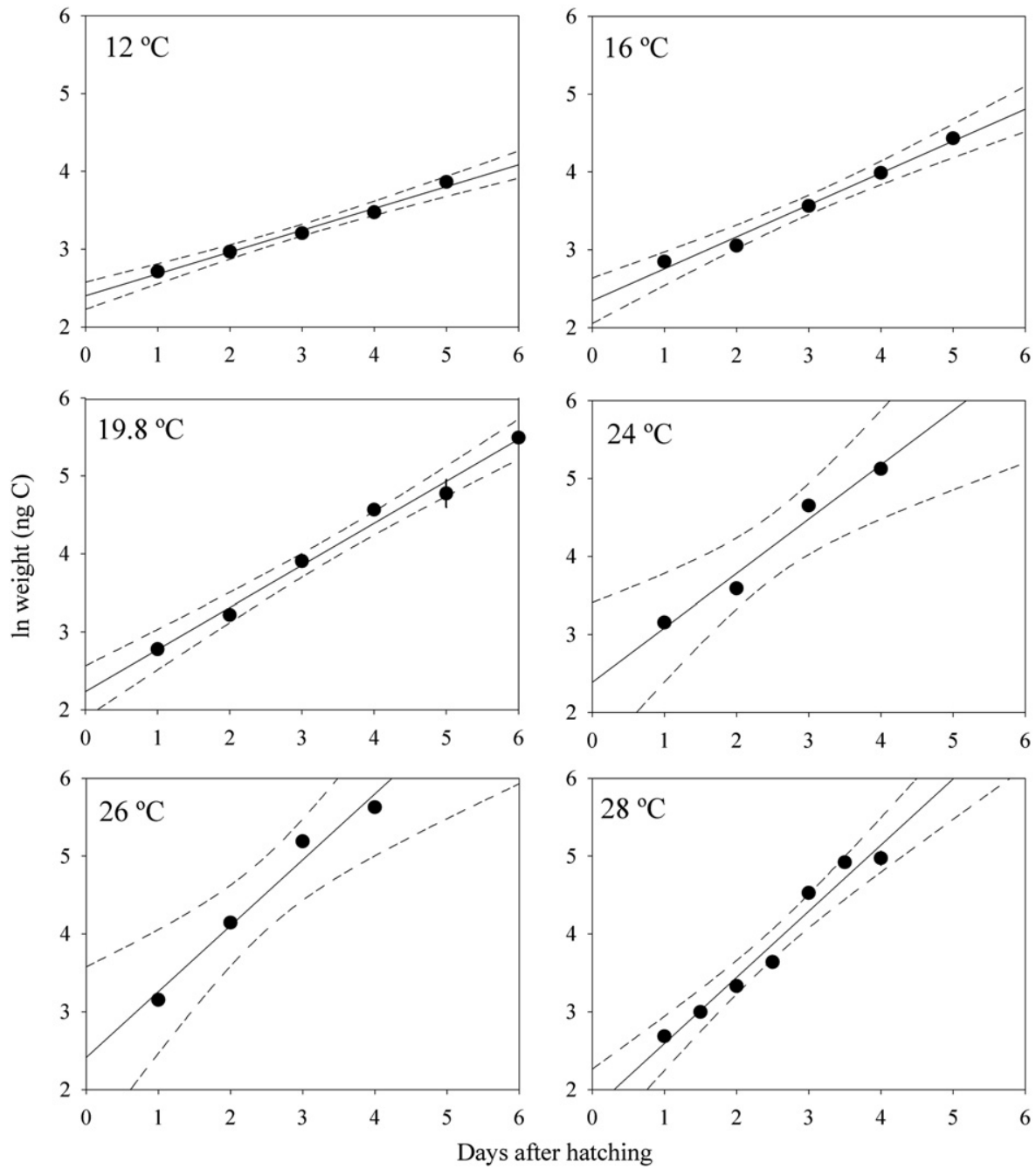

Fig. 1. Paracartia grani nauplii. Carbon content (ng C) increases at different temperatures. 

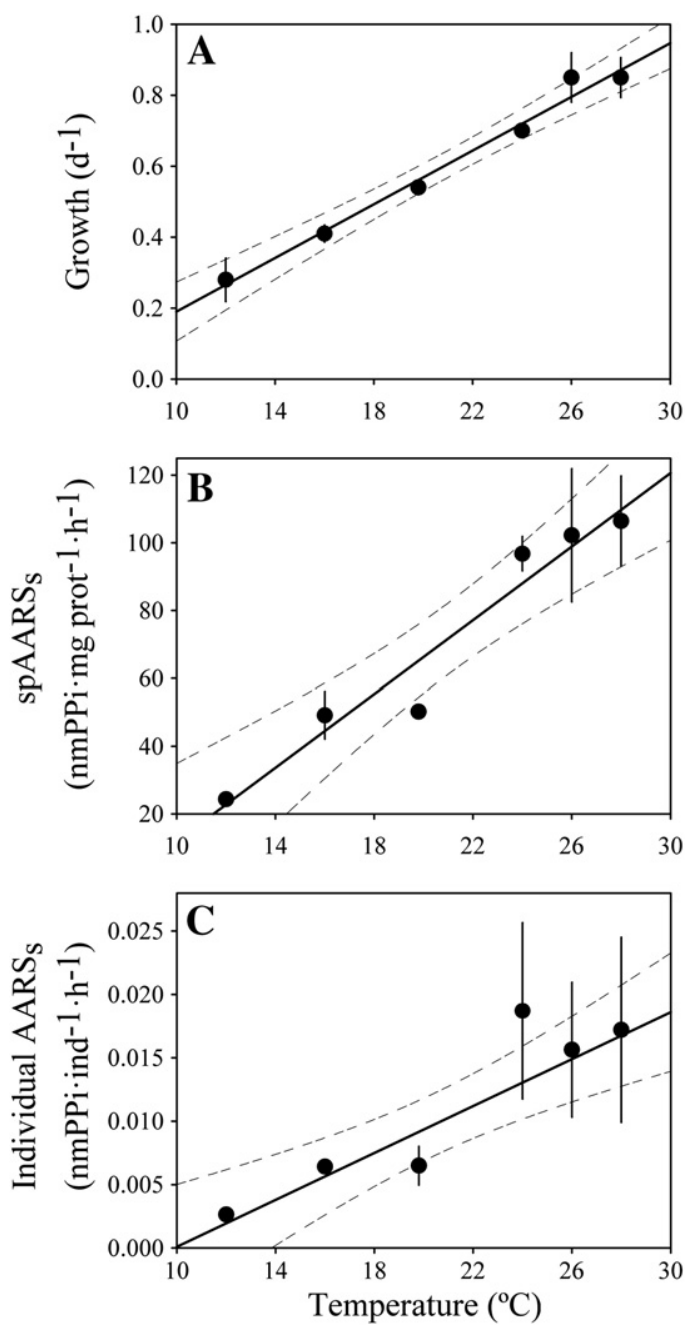

Fig. 2. Paracartia grani nauplii. Effect of temperature on $A)$ growth $\left.\left(d^{-1}\right), B\right) \operatorname{spAARS}_{\mathrm{s}}$ $\left.\left(\mathrm{nmPPi} \cdot \mathrm{mg} \mathrm{prot}^{-1} \cdot \mathrm{h}^{-1}\right), \mathrm{C}\right)$ individual AARS $\mathrm{s}\left(\mathrm{nmPPi} \cdot \mathrm{ind}^{-1} \cdot \mathrm{h}^{-1}\right)$.

that the aliquots frozen for biochemical assays contained a fixed amount of 1000 nauplii was not always correct, as observed on the protein content of the sample replicates (data not shown). This was mostly noted in the growth experiment conducted at a food concentration of $440 \mu \mathrm{g} C \cdot \mathrm{L}^{-1}$, which was excluded from fit calculations in Fig. 4C.

Growth rates $\left(d^{-1}\right)$ relative to food concentrations $\left(C, \mu g C \cdot L^{-1}\right)$ followed a saturation curve (Ivlev's equation, 1955) expressed by the function:

$G=0.65 \cdot\left(1-e^{(-0.013 \cdot C)}\right), r^{2}=0.986, p<0.001$

where 0.65 is the maximum growth rate $\left(\mathrm{d}^{-1}\right)$ and 0.013 is a constant that indicates the rate at which growth approaches the maximum rate. Naupliar growth became saturated at a food concentration level of $220 \mu \mathrm{g} \mathrm{C} \cdot \mathrm{L}^{-1}$ (Fig. 4A).

Individual $\mathrm{AARS}_{\mathrm{S}}\left(\mathrm{nmPPi} \cdot \mathrm{ind}^{-1} \cdot \mathrm{h}^{-1}\right)$ activities also increased with increasing food concentration (Fig. 4C), following a logarithmic model:

$A_{A R S} \cdot$ ind $^{-1}=0.0032+0.0004 \ln (C), r^{2}=0.907, p<0.05$

In contrast, specific AARS $\left(\mathrm{nmPPi} \cdot \mathrm{mg} \operatorname{prot}^{-1} \cdot \mathrm{h}^{-1}\right)$ exhibited three different values in relation to food concentration (Fig. 4B). Specific AARS showed maximum values $(59.31 \pm 0.29)$ from 0 to $11 \mu \mathrm{g} C \cdot \mathrm{L}^{-1}$, while between 55 and $110 \mu \mathrm{g} \mathrm{C} \cdot \mathrm{L}^{-1}$ the average spAARS was $46.27 \pm 0.24$. Above $220 \mu \mathrm{g} \mathrm{C} \cdot \mathrm{L}^{-1}$ spAARS $_{\mathrm{s}}$ remained low and rather constant $(33.78 \pm 0.78)$.

\subsection{Relationship between nauplii growth and protein synthesis rates}

Positive significant relationships were found between growth rates $\left(\mathrm{d}^{-1}\right)$ and both $\mathrm{spAARS}$ ( $\left.\mathrm{nmPPi} \cdot \mathrm{mg} \mathrm{prot}^{-1} \cdot \mathrm{h}^{-1}\right)$ and individual AARS $_{\mathrm{s}}\left(\mathrm{nmPPi} \cdot\right.$ ind $\left.^{-1} \cdot \mathrm{h}^{-1}\right)$ activities under food saturating conditions within the $12-28{ }^{\circ} \mathrm{C}$ range (Fig. 5):

$G=0.13+0.007 \cdot \operatorname{spAARS}_{\mathrm{s},} r^{2}=0.945, p<0.001$

$G=0.25+31.65 \cdot$ AARS $_{\mathrm{s}} \cdot$ ind $^{-1}, r^{2}=0.833, p<0.001$

A positive relationship between growth rates $\left(\mathrm{d}^{-1}\right)$ and individual AARS $_{\mathrm{S}}$ (nmPPi $\cdot$ ind $^{-1} \cdot \mathrm{h}^{-1}$ ) was also found within the 0-4000 cells $\cdot \mathrm{mL}^{-1}\left(0-880 \mu \mathrm{g} \mathrm{C} \cdot \mathrm{L}^{-1}\right)$ food concentration range (Fig. 6B):

$G=-0.59+204.46 \cdot$ AARS $_{s} \cdot$ ind $^{-1}, r^{2}=0.951, p<0.001$

However, the relationship between growth rates $\left(\mathrm{d}^{-1}\right)$ and spAARS $_{\mathrm{s}}$ activities (nmPPi $\cdot \mathrm{mg} \mathrm{prot}^{-1} \cdot \mathrm{h}^{-1}$ ) was negative (Fig. 6A):

$G=1.49-0.025 \cdot \operatorname{spAARS}_{\mathrm{s}}, r^{2}=0.958, p<0.0001$

Specific AARS activities (nmPPi $\cdot \mathrm{mg} \mathrm{prot}^{-1} \cdot \mathrm{h}^{-1}$ ) also showed a negative relationship with nauplii individual biomass ( $\mu$ g protein$\mathrm{s} \cdot$ ind $^{-1}$ ), presenting higher spAARS $_{\mathrm{s}}$ activities and lower individual biomass in starved organisms, and lower enzyme activities and higher protein content in the nauplii growing at food saturating levels (Fig. 7A):

spAARS $_{s}=64.3-165.0 \cdot$ individual biomass, $r^{2}=0.490, p<0.0001$

The relationship between daily growth rates and $\mathrm{spAARS}_{\mathrm{s}}$ in relation to the levels of food availability showed three different relationships (Fig. 7B):

Starvation level $\left(0-11 \mu \mathrm{g} \mathrm{C} \cdot \mathrm{L}^{-1}\right)$ :

$G=-0.141+0.0024 \cdot \operatorname{spAARS}_{\mathrm{s}}, r^{2}=0.458, p=0.095$

Intermediate level $\left(55-110 \mu \mathrm{g} C \cdot \mathrm{L}^{-1}\right)$ :

$G=-0.027+0.008 \cdot \operatorname{spAARS}_{s}, r^{2}=0.146, p=0.351$

Saturation level $\left(>220 \mu \mathrm{g} \mathrm{C} \cdot \mathrm{L}^{-1}\right)$ :

$G=-0.57+0.038 \cdot \operatorname{spAARS}_{s}, r^{2}=0.799, p=0.003$

\section{Discussion}

We assessed the effect of temperature and food concentration on somatic growth (calculated from length measurements) and protein synthesis rates (AARS activity) of $P$. grani nauplii. A strong relationship was observed between growth rate and specific AARS activity at saturating food concentration and at a wide range of temperatures. However, this strong relationship was not observed at different food levels, except for those incubated at saturation. High specific AARS activities were found at low growth rates under limiting food concentration and low individual biomass. Early nauplii stages do not feed but develop consuming lipid reserves. Whether this feature 

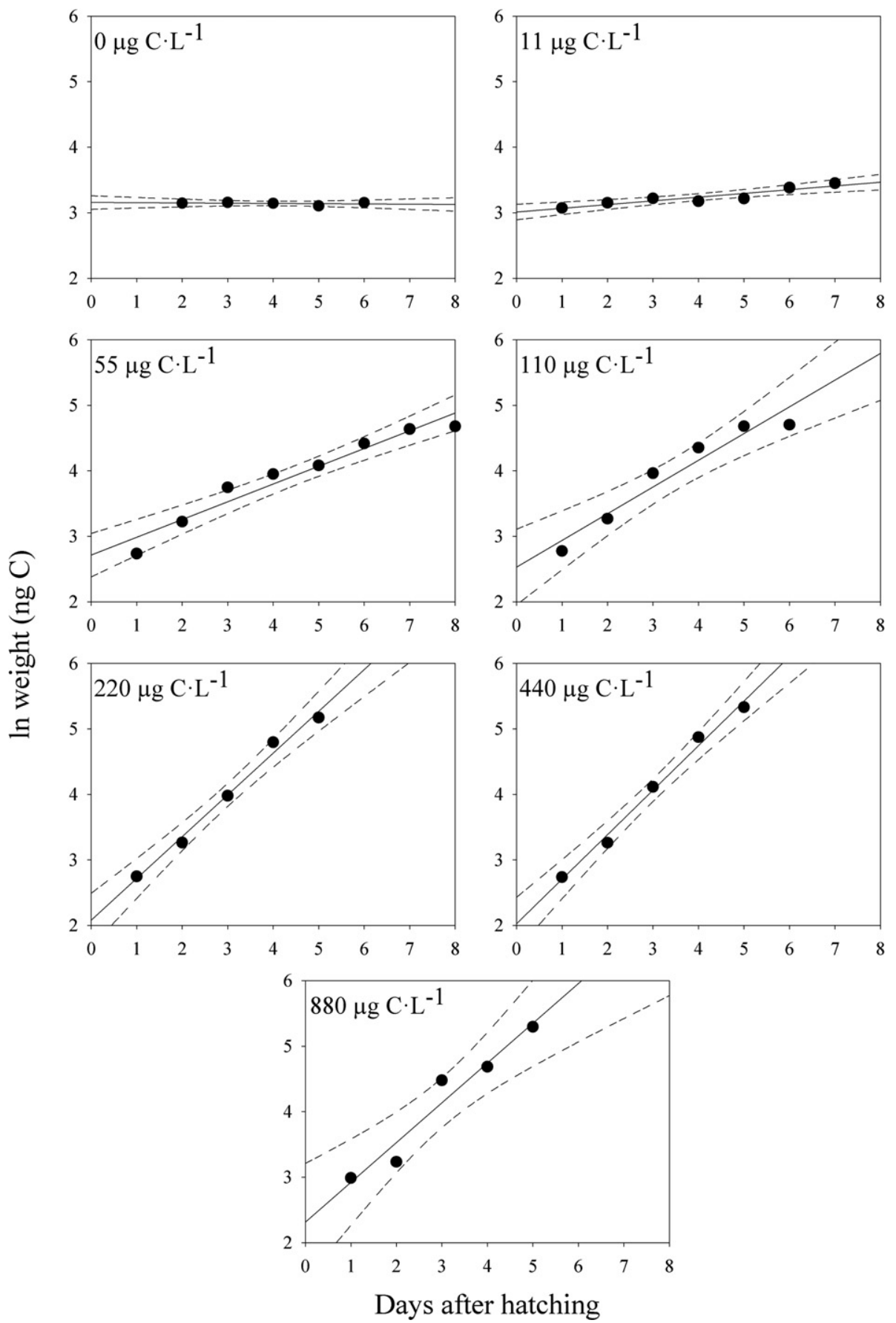

Fig. 3. Paracartia grani nauplii. Carbon content (ng C) increases under different food concentrations.

influences the relationship between growth rates and specific AARS activity seems the key to understanding the high activity observed in the present and other works (e.g., Holmborn et al., 2009) at low levels of food and growth.

\subsection{Effect of temperature}

Acartia species present isochronal development and exponential growth when reared at ad libitum food concentrations, and it has been shown that both growth and development rates depend on temperature (Klein Breteler and Schogt, 1994; Leandro and Tiselius, 2006; Leandro et al., 2006; Sekiguchi et al., 1980). Temperature had a positive effect on the naupliar growth and on the protein synthesis rates of these species when they were fed ad libitum. These naupliar growth rates were similar to those of other Acartia species nauplii (Table 3). The results obtained by Berggreen et al. (1988) and Leandro and Tiselius (2006) for Acartia tonsa agree with the rates of P. grani observed by Calbet and Alcaraz (1997) and those found in the present work within the $10-18{ }^{\circ} \mathrm{C}$ temperature range. However, at $22^{\circ} \mathrm{C}$ A. tonsa grew faster (Leandro and Tiselius, 2006) than P. grani. This might be due to the different quality of the food supplied (Table 3), but also to the different responses that these species may have with increasing temperature. For example, A. tonsa is distributed worldwide (Kouwenberg, 2011), while P. grani is found in coastal NE Atlantic and Mediterranean Sea waters (Walter and Boxshall, 2011). Also, the temperature quotients $\left(Q_{10}\right)$ observed for both growth and protein synthesis rates in $P$. grani $\left(2.1\right.$ between 16 and $26{ }^{\circ} \mathrm{C}$ ) were lower than the $Q_{10}$ values reported by Leandro and Tiselius (2006) 

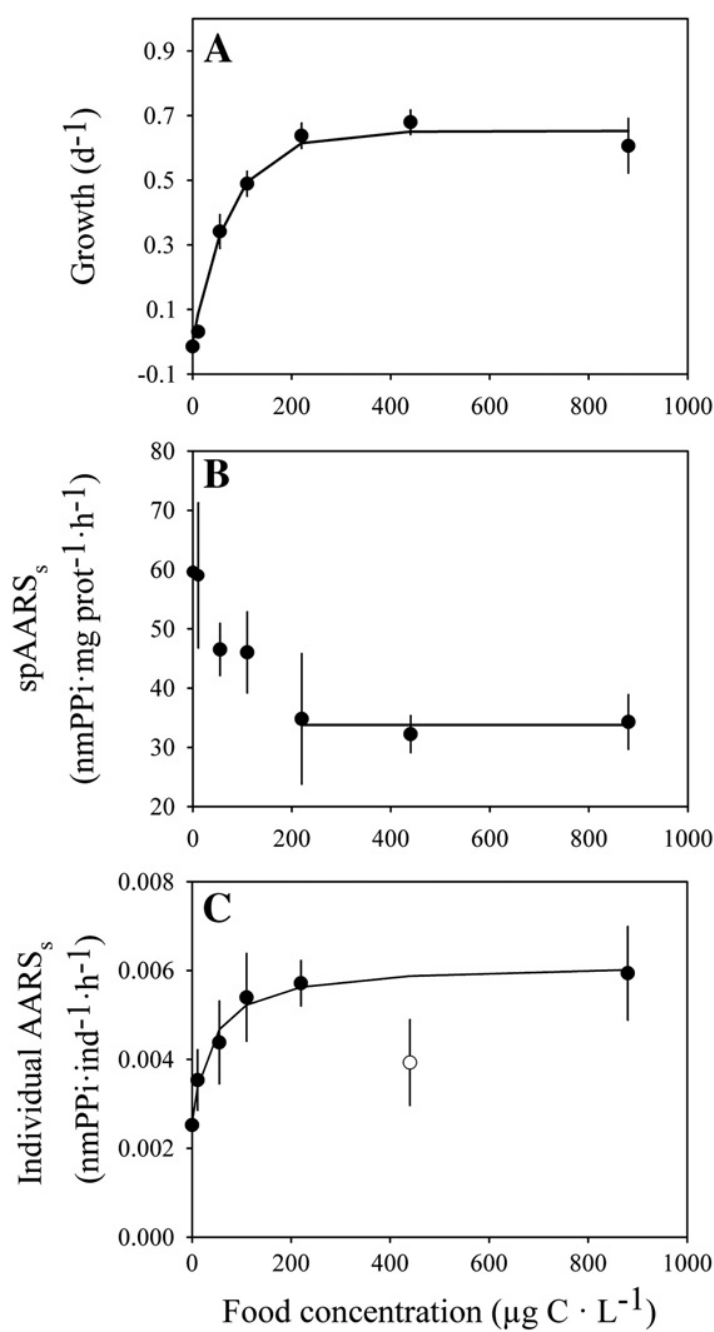

Fig. 4. Paracartia grani nauplii. Effect of food concentration on A) growth $\left(d^{-1}\right)$, B) $\left.\operatorname{spAARS}_{\mathrm{s}}\left(\mathrm{nmPPi} \cdot \mathrm{mg} \operatorname{prot}^{-1} \cdot \mathrm{h}^{-1}\right), \mathrm{C}\right)$ individual AARS $\left(\mathrm{nmPPi} \cdot\right.$ ind $\left.^{-1} \cdot \mathrm{h}^{-1}\right)$; open circle: value not included in fit (see text).

(3.66 between 10 and $22^{\circ} \mathrm{C}$ ). However, the use of $\mathrm{Q}_{10}$ values calculated across different temperature ranges could result in errors when comparing the temperature effects on physiological rates, as the $Q_{10}$ has been shown to be temperature dependent, decreasing when temperature rises (Almeda et al., 2010).

\subsection{Effect of food availability}

As expected, growth rates of $P$. grani depended on the food availability. At low food concentration a low growth rate was observed in $P$. grani nauplii. This fact might be explained by a decreased efficiency of food capture at low food concentration, as observed for other congeneric species (Paffenhöfer and Stearns, 1988: A. tonsa), suggesting their adaptation to the high food environments in which they are mainly found (estuarine areas and coastal waters, Alcaraz, 1977; Villate, 1982). At high food concentrations growth rate became stable for $P$. grani nauplii, as was previously observed for this (Calbet and Alcaraz, 1997: A. grani) and other species (Berggreen et al., 1988: A. tonsa) at the same temperature $18^{\circ} \mathrm{C}$, but feeding on a different food type ( $R$. baltica). There are several studies on the effect of the quality and food concentration on the egg-production rates, growth and development of the genus Acartia (Berggreen et al., 1988; Calliari and Tiselius, 2005; Hassett, 2004; Stottrup and Jensen, 1990). However, the effect of the food type on the growth of early stages of copepods is scarcely studied. The prey used in this study

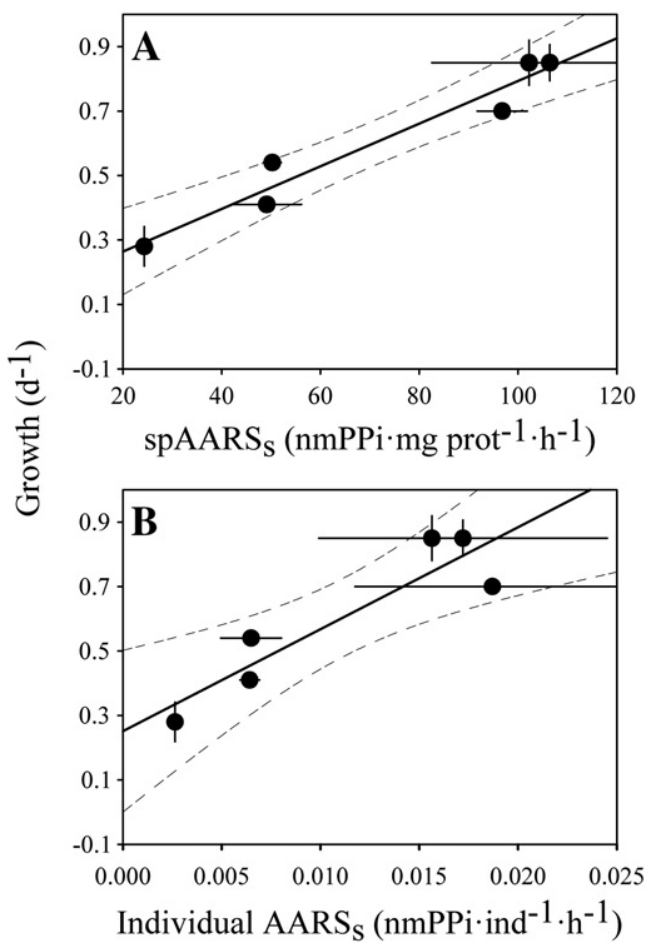

Fig. 5. Paracartia grani nauplii. Relationship between growth rates $\left(d^{-1}\right)$ and $\left.A\right)$ specific AARS $_{\mathrm{s}}$ activities (nmPPi $\left.\left.\cdot \mathrm{mg} \mathrm{prot}^{-1} \cdot \mathrm{h}^{-1}\right), \mathrm{B}\right)$ individual AARS $\left(\mathrm{nmPPi} \cdot \mathrm{ind}^{-1} \cdot \mathrm{h}^{-1}\right)$ at different temperatures $\left({ }^{\circ} \mathrm{C}\right)$.

(O. marina) is considered a high-quality food for Acartia species (Klein Breteler and Schogt, 1994; Kleppel et al., 1998), although other studies used different prey ( $R$. baltica or a mixture of the diatom Thalassiosira weissflogii and the cryptophyte Rhodomonas sp.). It has been shown that diet modification affects Acartia species growth,

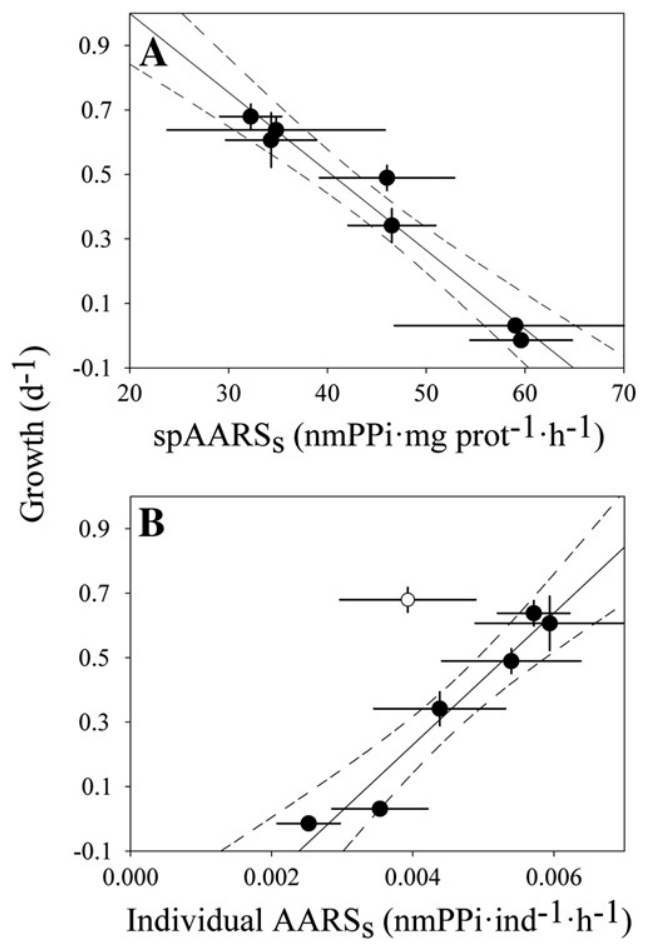

Fig. 6. Paracartia grani nauplii. Relationship between growth rates $\left(\mathrm{d}^{-1}\right)$ and $\left.A\right)$ specific AARS $_{\mathrm{s}}$ activities (nmPPi $\left.\left.\cdot \mathrm{mg} \mathrm{prot}^{-1} \cdot \mathrm{h}^{-1}\right), \mathrm{B}\right)$ individual AARS $\left(\mathrm{nmPPi} \cdot \mathrm{ind}^{-1} \cdot \mathrm{h}^{-1}\right.$ ) under different food concentrations $\left(\mu \mathrm{g} \mathrm{C} \cdot \mathrm{L}^{-1}\right)$; open circle: value not included in fit (see text). 

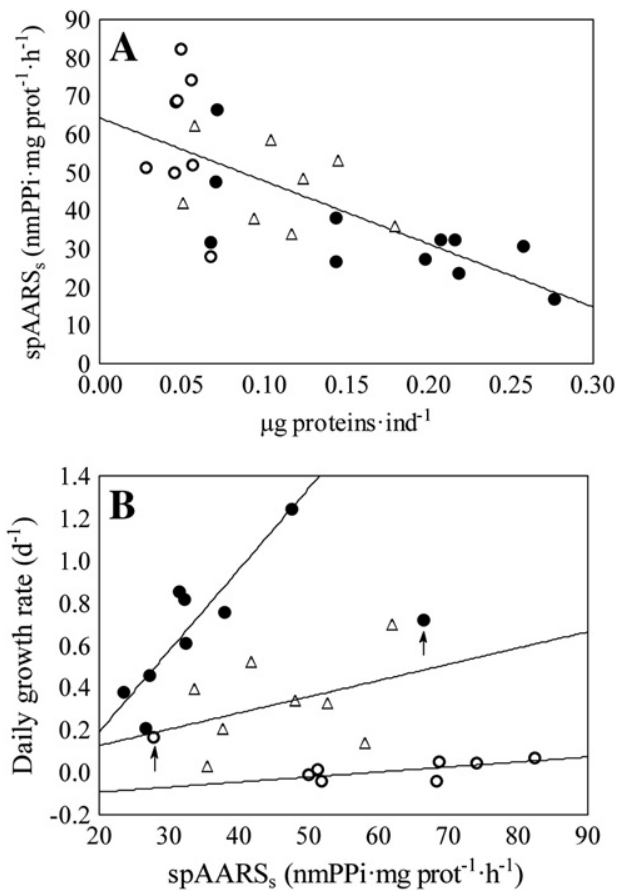

Fig. 7. Paracartia grani nauplii. A) Relationship between specific $A_{A R S}$ activities $\left(\mathrm{nmPPi} \cdot \mathrm{mg} \mathrm{prot}^{-1} \cdot \mathrm{h}^{-1}\right)$ and individual biomass $\left(\mu \mathrm{g}\right.$ proteins $\cdot$ ind $\left.^{-1}\right)$; B) Relationships between daily growth rates $\left(\mathrm{d}^{-1}\right)$ and specific AARS activities $\left(\mathrm{nmPPi} \cdot \mathrm{mg} \mathrm{prot}^{-1} \cdot \mathrm{h}^{-1}\right)$ under different food concentrations (open circles: starvation level, triangles: intermediate level, filled circles: saturation level); arrows: values not included in fit.

development, production, and nutritional composition (Ismar et al., 2008; Teixeira et al., 2010). Nevertheless, the growth rate of naupliar stages of $P$. grani at $18{ }^{\circ} \mathrm{C}\left(0.50 \mathrm{~d}^{-1}\right.$, calculated from Eq. (1)) was comparable to those observed on nauplii of this and other congeneric species (Table 3) despite the different prey supplied as food. This fact

Table 3

Summary of published Acartia spp. nauplii growth rates under saturating food levels.

\begin{tabular}{|c|c|c|c|c|}
\hline $\begin{array}{l}\text { Temperature } \\
\left({ }^{\circ} \mathrm{C}\right)\end{array}$ & $\begin{array}{l}\text { Growth rate } \\
\left(\mathrm{d}^{-1}\right)\end{array}$ & Species & Food type & Reference \\
\hline 10 & 0.19 & $\begin{array}{l}\text { Acartia } \\
\text { clausi }\end{array}$ & Rhodomonas sp. & Leandro et al., 2006 \\
\hline 10 & 0.19 & $\begin{array}{l}\text { Acartia } \\
\text { tonsa }\end{array}$ & Rhodomonas sp. & $\begin{array}{l}\text { Leandro and } \\
\text { Tiselius, } 2006\end{array}$ \\
\hline 12 & 0.28 & $\begin{array}{l}\text { Paracartia } \\
\text { grani }\end{array}$ & $\begin{array}{l}\text { Oxyrrhis } \\
\text { marina }\end{array}$ & This work \\
\hline 15 & 0.27 & A. clausi & Rhodomonas sp. & Leandro et al., 2006 \\
\hline 15 & 0.37 & A. tonsa & Rhodomonas sp. & $\begin{array}{l}\text { Leandro and } \\
\text { Tiselius, } 2006\end{array}$ \\
\hline 16 & 0.41 & P. grani & O. marina & This work \\
\hline 16 & 0.41 & A. tonsa & $\begin{array}{l}\text { Rhodomonas } \\
\text { baltica }\end{array}$ & $\begin{array}{l}\text { Berggreen et al., } \\
1988\end{array}$ \\
\hline 18 & 0.46 & P. grani & R. baltica & $\begin{array}{l}\text { Calbet and Alcaraz, } \\
1997\end{array}$ \\
\hline 18 & 0.45 & A. tonsa & R. baltica & $\begin{array}{l}\text { Berggreen et al., } \\
1988\end{array}$ \\
\hline 18 & 0.46 & A. clausi & Rhodomonas sp. & Leandro et al., 2006 \\
\hline 18 & 0.54 & A. tonsa & Rhodomonas sp. & $\begin{array}{l}\text { Leandro and } \\
\text { Tiselius, } 2006\end{array}$ \\
\hline 19.8 & 0.53 & P. grani & O. marina & This work \\
\hline 20 & 0.42 & A. clausi & Rhodomonas sp. & Leandro et al., 2006 \\
\hline 20 & $0.61-0.68$ & P. grani & O. marina & This work \\
\hline 22 & 0.42 & A. clausi & Rhodomonas sp. & Leandro et al., 2006 \\
\hline 22 & 0.88 & A. tonsa & Rhodomonas sp. & $\begin{array}{l}\text { Leandro and } \\
\text { Tiselius, } 2006\end{array}$ \\
\hline 24 & 0.70 & P. grani & O. marina & This work \\
\hline 26 & 0.85 & P. grani & O. marina & This work \\
\hline 28 & 0.85 & P. grani & O. marina & This work \\
\hline
\end{tabular}

suggests that food quality might not strongly affect nauplii growth rates of these species under saturating food concentrations.

\subsection{Relationship between somatic growth and protein synthesis rates}

Somatic growth and protein synthesis rates in $P$. grani nauplii were affected by temperature and food concentration. We found positive relationships between somatic growth and protein synthesis rates of nauplii feeding at ad libitum food concentrations. This is in agreement with the significant correlations previously observed between somatic growth rates and specific $\mathrm{AARS}_{\mathrm{s}}$ activities in copepodites and adults of other calanoid species (Yebra et al., 2005, 2006), both in laboratory and field experiments.

Protein-specific and individual $\mathrm{AARS}_{\mathrm{s}}$ activities of $P$. grani nauplii showed patterns similar to growth at different temperatures when feeding ad libitum. We also observed a similar pattern between growth rates and individual $\mathrm{AARS}_{\mathrm{S}}$ in relation to food availability. However, contrary to expectations, the relationship between specific $\mathrm{AARS}_{\mathrm{S}}$ activities and growth rates was negative (Fig. 6A). P. grani nauplii specific $A A R S_{s}$ activities also showed a negative relationship with individual biomass (Fig. 7A), and presented three different relationships with growth, corresponding to organisms either starved, under food saturating conditions or growing at intermediate food levels (Fig. 7B). Under starvation $\left(0-11 \mu \mathrm{g} \mathrm{C} \cdot \mathrm{L}^{-1}\right)$, P. grani nauplii metabolic activities were maintained at the expense of accumulated endogenous energy reserves, resulting in either negative or almost nil growth rates $\left(-0.01-0.03 \mathrm{~d}^{-1}\right)$ and low individual $\mathrm{AARS}_{\mathrm{s}}$, but very high specific $A A R S_{s}$ activities. On the contrary, nauplii feeding on saturating food concentrations showed a clear relationship between growth rates and specific $\mathrm{AARS}_{\mathrm{s}}$ activity. This observed variability could be due to one or, most probably, different factors combined, such as i) food limitation of growth and protein synthesis rates, ii) the relative importance of the protein turnover rates in relation to the 'de novo' protein synthesis rates of the nauplii, which would lead to anomalously high $\mathrm{spAARS}_{\mathrm{S}}$ values on organisms under starvation, as previously observed in A. bifilosa females by Holmborn et al. (2009), and Oithona davisae nauplii by Yebra et al. (2011); iii) the body size of the nauplii (as suggested by the relationship observed between $\operatorname{spAARS}_{\mathrm{s}}$ activity and individual biomass) and iv) the different developmental stages reached by the nauplii in each food treatment. In this sense, under low food conditions nauplii may not reach their first feeding stage, and the pre-feeding stages might have different protein metabolism and growth pathways that the feeding ones. Protein growth is defined as the change in mass of the protein pool and can be either positive or negative depending on the relative balance between protein synthesis and degradation (see Fraser and Rogers, 2007). Thus, a first case to explain the observed results could be related to the fact that in actively feeding organisms (above $55 \mu \mathrm{g} \mathrm{C} \cdot \mathrm{L}^{-1}$ in this study), rates of protein synthesis would be greater than protein degradation and hence somatic growth will occur. However, in starved organisms (0-11 $\mu \mathrm{g} \mathrm{C} \cdot \mathrm{L}^{-1}$ in this study) proteins are degraded faster than they are synthesized (Hawkins, 1985). Previous studies on the effect of the frequency of feeding on both overall growth and protein metabolism in the European lobster showed elevated protein synthesis rates but also elevated degradation, resulting in high turnover and reduced growth (Mente et al., 2001). Then, the observed high protein-specific AARS values could be explained by the coupling of the nauplii protein mass decrease due to starvation (or insufficient food for growth) and their high turnover rates. A second case could be methodological as non-feeding organisms may use their lipid reserves to survive. The ß-oxidation of fatty acids could produce PPi during the assay which would interfere in our method because we measure AARS activity as PPi release rate. This precludes the application of this method on organisms living on the degradation of their own lipid reserves. These problems should be tested by measuring enzyme activity using radioactive substrates. In any case, this mismatch between 
specific AARS activity and growth rates due to artificially induced low food concentrations would not likely occur in the field for this species, considering that typical particulate organic carbon values observed in their coastal habitats lay above those experimental food levels (Duforet-Gaurier et al., 2010; Gardner et al., 2006; Huntley and Boyd, 1984).

Summarizing, both growth and protein synthesis rates of $P$. grani nauplii depended on temperature and food concentration. AARS activity is valid as index of somatic growth for $P$. grani nauplii when growth is not limited by food availability. However the degradation of proteins during starvation and/or the use of lipids as fuel in prefeeding nauplii affected the relationship between specific AARS activity and growth rates. The results presented here add to previous studies showing that the AARS s activity is a useful tool for estimating somatic growth in copepods. Nevertheless, further investigations are required to elucidate the possible effects of size, lipids and protein metabolism in order to use AARS activity as a universal proxy for growth.

\section{Acknowledgments}

We thank the members of the Zooplankton Ecology Group at the Institute of Marine Sciences (ICM, Barcelona, Spain) for their help. The study was funded by a Canary Government travel grant and a Cabildo de Gran Canaria PhD fellowship (Decreto 53/07) to I. H. It was also supported by the European Social Fund (I3P-CSIC Programme contract to L.Y.) and by projects Oithona (CTM2007-60052) and Lucifer (CTM2008-03538/MAR). [SS]

\section{References}

Alcaraz, M., 1977. Ecología, competencia y segregación de especies congenéricas de copépodos (Acartia). PhD Thesis, University of Barcelona, Spain, $191 \mathrm{pp}$.

Almeda, R., Calbet, A., Alcaraz, M., Yebra, L., Saiz, E., 2010. Effect of temperature and food concentration on survival, development and growth rates of naupliar stages of Oithona davisae (Copepoda, Cyclopoida). Mar. Ecol. Prog. Ser. 410, 97-109.

Bergeron, J.P., Buestel, D., 1979. L'Aspartate transcarbamylase, indice de l'activite' sexuelle de la coquille Saint-Jaques (Pecten maximus L.). Premier resultats. In: Naylor, E., Hartnoll, R.G. (Eds.), Cyclic Phenomena in Marine Plants and Animals. Pergamon Press, New York, pp. 301-308.

Berges, J.A., Roff, J.C., Ballantyne, J.S., 1990. Relationships between body size, growth rate and maximal enzyme activities in the brine shrimp, Artemia franciscana. Biol. Bull. 179, 287-296.

Berggreen, U., Hansen, B., Kiørboe, T., 1988. Food size spectra ingestion and growth of the copepod Acartia tonsa during development: implications for determination of copepod production. Mar. Biol. 99, 341-352.

Bersano, J.G.F., 2000. Field and laboratory studies on the effect of the Texas brown tide alga Aureoumbra lagunensis on copepods Acartia tonsa. Ph.D dissertation, Texas A\&M University.

Biegala, I.C., Bergeron, J.P., 1998. Optimal assay conditions for aspartate transcarbamylase (ATCase) activity in mesozooplankton. J. Plankton Res. 20, 1205-1218.

Calbet, A., Alcaraz, M., 1997. Growth and survival rates of early developmental stages of Acartia grani (Copepoda: Calanoida) in relation to food concentration and fluctuations in food supply. Mar. Ecol. Prog. Ser. 147, 181-186.

Calliari, D., Tiselius, P., 2005. Feeding and reproduction in a small calanoid copepod: Acartia clausii can compensate quality with quantity. Mar. Ecol. Prog. Ser. 298, 241-250.

Dagg, M.J., Littlepage, J.L., 1972. Relationships between growth rate and RNA, DNA, protein and dry weight in Artemia salina and Eucheta elongate. Mar. Biol. 17, 162-170.

Duforet-Gaurier, L., Loisel, H., Dessailly, D., Nordkvist, K., Alvain, S., 2010. Estimates of particulate organic carbon over the euphotic depth from in situ measurements. Application to satellite data over the global ocean. Deep-Sea Res. I. 57, 351-367.

Durbin, E.G., Durbin, A.G., 1978. Length and weight relationships of Acartia clausi from Narragansett Bay, R.I. Limnol. Oceanogr. 23, 958-969.

Fraser, K.P.P., Rogers, A.D., 2007. Protein metabolism in marine animals: the underlying mechanism of growth. Adv. Mar. Biol. 52, 267-362.

Gardner, W.D., Mishonov, A.V., Richardson, M.J., 2006. Global POC concentrations from in-situ and satellite data. Deep-Sea Res. II. 53, 718-740.

Gorokhova, E., 2003. Relationships between nucleic acid levels and egg production rates in Acartia bifilosa: implications for growth assessment of copepods in situ. Mar. Ecol. Prog. Ser. 262, 163-172.

Guerra, C., 2006. Bestimmung von Wachstumsraten bei larvalem Krill (Euphausia superba) im antarktischen Herbst in der Lazarev-See - Ein Vergleich verschiedener methodischer Ansaätze -. Diplom, Universität Bremen.

Guillard, R.R.L., 1975. Culture of Phytoplankton for Feeding Marine Invertebrates. In: Smith, W.L., Chanley, M.H. (Eds.), Culture of marine invertebrate animals. Plenum Press, New York, pp. 29-60.

Hassett, R., 2004. Supplementation of a diatom diet with cholesterol can enhance copepod egg-production rates. Limnol. Oceanogr. 49, 488-494.
Hawkins, A.J.S., 1985. Relationships between the synthesis and breakdown of protein dietary absorption and turnovers of nitrogen and carbon in the blue mussel, Mytilus edulis L. Oecologia 66, 42-49.

Heinle, D.R., 1966. Production of the calanoid copepod, Acartia tonsa, in the Patuxent River estuary. Chesapeake Sci. 7, 59-74.

Hirst, A.G., Bunker, A.J., 2003. Growth of marine planktonic copepods: global rates and patterns in relation to chlorophyll a, temperature, and body weight. Limnol. Oceanogr. 48, 1988-2010.

Hirst, A.G., McKinnon, A.D., 2001. Does egg production represent adult female copepod growth? A call to account for body weight changes. Mar. Ecol. Prog. Ser. 223, 179-199.

Hirst, A.G., Roff, J.C., Lampitt, R.S., 2003. A synthesis of growth rates in marine epipelagic invertebrate zooplankton. Adv. Mar. Biol. 44, 1-142.

Holmborn, T., Dahlgren, K., Holeton, C., Hogfors, H., Gorokhova, E., 2009. Biochemical proxies for growth and metabolism in Acartia bifilosa (Copepoda, Calanoida). Linmol. Oceanogr. Methods 7, 785-794.

Huntley, M., Boyd, C., 1984. Food-limited growth of marine zooplankton. Am. Nat. 124 $455-478$.

Ismar, S.M.H., Hansen, T., Sommer, U., 2008. Effect of food concentration and type of diet on Acartia survival and naupliar development. Mar. Biol. 154, 335-343.

Ivlev, V.S., 1955. Experimental Ecology of the Feeding of Fishes. Yale University Press New Haven.

Jones, M.E., 1980. Pyrimidine nucleotide biosynthesis in animals: genes, enzymes, and regulation of UMP biosynthesis. Annu. Rev. Biochem. 49, 253-279.

Klein Breteler, W.C.H., Gonzalez, S.R., 1982. Influence of cultivation and food concentration on body length of calanoid copepods. Mar. Biol. 71, 157-161.

Klein Breteler, W.C.M., Schogt, N., 1994. Development of Acartia clausi (Copepoda, Calanoida) cultured at different conditions of temperature and food. Hydrobiologia 292, 469-479.

Kleppel, G.S., Burkart, C.A., Houchin, L., 1998. Nutrition and the regulation of egg production in the calanoid copepod Acartia tonsa. Limnol. Oceanogr. 43, 1000-1007.

Kouwenberg, J., 2011. Acartia (Acanthacartia) tonsa Dana, 1849. In: Walter, T.C., Boxshall, G. (Eds.), (World Copepoda database).

Landry, M.R., 1978. Population dynamics and production of a planktonic marine copepod, Acartia clausi, in a small temperate lagoon on San Juan Island; Washington. Int. Rev. Ges. Hydrobiol. 63, 77-119.

Leandro, S.M., Tiselius, P., 2006. Growth and development of nauplii and copepodites of the estuarine copepod Acartia tonsa from southern Europe (Ria de Aveiro, Portugal) under saturating food conditions. Mar. Biol. 150, 121-129.

Leandro, S.M., Queiroga, H., Rodríguez-Graña, L., Tiselius, P., 2006. Temperature-dependent development and somatic growth in two allopatric populations of Acartia clausi (Copepoda: Calanoida). Mar. Ecol. Prog. Ser. 322, 189-197.

Lowry, P.H., Rosenbrough, N.J., Farr, A.L., Randall, R.J., 1951. Protein measurement with Folin phenol reagent. J. Biol. Chem. 193, 265-275.

Marshall, S.M., Orr, A.P., 1955. The biology of a marine copepod - Calanus finmarchicus Gunnerus. Oliver \& Boyd, London.

Mente, E., Houlihan, D.F., Smith, K., 2001. Growth, feeding frequency, protein turnover, and amino acid metabolism in European lobster Homarus gammarus L. J. Exp. Zool 289, 419-432.

Oosterhuis, S.S., Baars, M.A., Klein Breteler, W.C.M., 2000. Release of the enzyme chitobiase by the copepod Temora longicornis: characteristics and potential tool for estimating crustacean biomass production in the sea. Mar. Ecol. Prog. Ser. 196, 195-206.

Paffenhöfer, G.A., Stearns, D.E., 1988. Why is Acartia tonsa (Copepoda: Calanoida) restricted to nearshore environments? Mar. Ecol. Prog. Ser. 42, 33-38.

Postel, L., Fock, H., Hagen, W., 2000. Biomass and abundance. In: Harris, R.P., Wiebe, P.H., Lenz, J., Skjoldal, H.R., Huntley, M. (Eds.), ICES Zooplankton Methodology Manual. Academic Press, London/San Diego, pp. 83-192.

Rosamma, S., Rao, T.S.S., 1985. On the species of Acartiidae (Copepoda: Calanoida) collected during the international Indian Ocean expedition. Mahasagar Bull. Natl. Inst. Oceanogr. 18, 467-476.

Runge, J.A., Roff, J.C., 2000. The measurement of growth and reproductive rates. In: Harris, R.P., Wiebe, P.H., Lenz, J., Skjoldal, H.R., Huntley, M. (Eds.), ICES Zooplankton Methodology Manual. Academic Press, London/San Diego, pp. 401-454.

Rutter, W.J., 1967. Protein determinations in embryos. In: Wilt, F.H., Wessels, N.K. (Eds.), Methods in developmental biology. Academic Press, London, pp. 671-684.

Saiz, E., Calbet, A., Trepat, I., Irigoien, X., Alcaraz, M., 1997. Food availability as a potential source of bias in the egg production method for copepods. J. Plankton Res. 19, 1-14.

Saiz, E., Calbet, A., Fara, A., Berdalet, E., 1998. RNA content of copepods as a tool for determining adult growth rates in the field. Limnol. Oceanogr. 43, 465-470.

Sars, G.O., 1904. Description of Paracartia grani, G.O. Sars, a peculiar calanoid occurring in some of the oyster-beds of western Norway. Bergens Mus. Aarbog 4, 1-16 (6 pls).

Sastri, A.R., Roff, J.C., 2000. Rate of chitobiase degradation as a measure of development rate in planktonic Crustacea. Can. J. Fish. Aquat. Sci. 57, 1965-1968.

Sekiguchi, H., McLaren, I.A., Corkett, C.J., 1980. Relationships between rates of growth and reproduction in the copepod Acartia clausi hudsonica. Mar. Biol. 58, 133-138.

Stottrup, J., Jensen, J., 1990. Influence of algal diet on feeding and egg-production of the calanoid copepod Acartia tonsa Dana. J. Exp. Mar. Biol. Ecol. 141, 87-105.

Teixeira, P.F., Kaminski, S.M., Avila, T.R., Cardozo, A.P., Bersano, G.F., Bianchini, A., 2010. Diet influence on egg production of the copepod Acartia tonsa (Dana, 1896). Ann. Braz. Acad. Sci. 82, 333-339.

Villate, F., 1982. Contribución al conocimiento de las especies de Acartia autoctonas de zonas salobres: Acartia (Paracartia) grani, G.O. Sars en la ria de Mundaka (Vizcaya, España). Kobie 12, 76-81.

Wagner, M.M., Campbell, R.G., Boudreau, C.A., Durbin, E.G., 2001. Nucleic acids and growth of Calanus finmarchicus in the laboratory under different food and temperature conditions. Mar. Ecol. Prog. Ser. 221, 185-197. 
Walter, T.C., Boxshall, G., 2011. Paracartia grani Sars G.O., 1904. In: Walter, T.C., Boxshall, G. (Eds.), (World Copepoda database).

Yebra, L., Hernández-León, S., 2004. Aminoacyl-tRNA synthetases activity as a growth index in zooplankton. J. Plankton Res. 26, 351-356.

Yebra, L., Harris, R.P., Smith, T., 2005. Growth of Calanus helgolandicus later developmental stages (CV-CVI): comparison of four methods of estimation. Mar. Biol. 147, 1367-1375.
Yebra, L., Hirst, A.G., Hernández-León, S., 2006. Assessment of Calanus finmarchicus growth and dormancy using the aminoacyl-tRNA synthetases method. J. Plankton Res. 28, 1191-1198.

Yebra, L., Berdalet, E., Almeda, R., Pérez, V., Calbet, A., Saiz, E., 2011. Protein and nucleic acid metabolism as proxies for growth and fitness of Oithona davisae (Copepoda, Cyclopoida) early developmental stages. J. Exp. Mar. Biol. Ecol. 406, 87-94. 